Scraps of Home : Banda Acehnese Life Narratives Contesting the Reconstruction Discourse of a Post-Tsunami City that is pÿ Built Back Better

\author{
Jauhola, Kati Marjaana \\ 2015
}

Jauhola, K M 2015 , ' Scraps of Home : Banda Acehnese Life Narratives Contesting the pÿReconstruction Discourse of a Post-Tsunami City that is Built Back Better ' , Asian Journal of Social Science , vol. 43 , no. 6 , pp. 738 . https://doi.org/10.1163/15685314-04306005

http://hdl.handle.net/10138/158804

https://doi.org/10.1163/15685314-04306005

publishedVersion

Downloaded from Helda, University of Helsinki institutional repository.

This is an electronic reprint of the original article.

This reprint may differ from the original in pagination and typographic detail.

Please cite the original version. 


\title{
Scraps of Home
}

\section{Banda Acehnese Life Narratives Contesting the Reconstruction Discourse of a Post-Tsunami City that is "Built Back Better"}

\author{
Marjaana Jauhola* \\ University of Helsinki
}

\begin{abstract}
Global vulnerability to natural hazards has increased in recent years but, as they represent complex intersection of social, political and economic factors, their impacts do not affect people equally. Simultaneously, a paradigm of "build back better" has emerged as a global agenda to promote resilience and continuum of relief, recovery and longerterm development. This article offers insights into the complexities of rebuilding by focusing on personal narratives collected between 2012 and 2015 in the aftermath of the December 2004 Indian Ocean earthquake and ensuing tsunami. It offers seven accounts of how lived and embodied experiences of home and belonging in the postdisaster city of Banda Aceh offer modes of contestation for the concept of an Aceh that "is built back better". Following the lives of people through their everyday experiences offers insights into the relations of power and the potential structures of violence that are embedded in the aftermath: layered exiles and displacement; hidden narratives of violence and grief; struggles over gendered expectations of being a good and respectable woman and man; the hierarchical political economy of post-conflict and tsunami reconstruction; and multiple ways of arranging lives and remembrance, cherishing loved ones and forming caring and loving relationships outside the normative notions of nuclear family and home.
\end{abstract}

\section{Keywords}

tsunami - Banda Aceh - home - belonging - lived experience-gender - intersectional social inequalities

* The author wishes to thank the special issue editors and two anonymous reviewers for their comments of the earlier versions of the article. 


\section{Introduction: Turning towards the Mundane Everyday}

The past few decades has witnessed a steady rise in natural hazards, such as earthquakes, cyclones, landslides and floods. Their impacts on people's lives and livelihoods are severe. As feminist disaster scholars have drawn attention to for decades, vulnerability to the impacts of natural hazards is a result of a complex intersection of social, political and economic environments: gender, race, religion, ethnicity, language, class and caste and other social categories are essential elements when analysing the social dimensions of disaster aftermath (see, for example, Enarson and Fordham, 2001; Enarson and Meyreles, 2004). Yet, as scholars have pointed out, these intersectional relationships to disasters may in their disaster policy usage become de-politicised and used without deeper understanding of the socio-historical contexts (Carrigan, 2016: 205).

Thus, disaster reconstruction efforts are never "just" technical. Rather, disaster affected individuals navigate through reconstruction interventions with varying degrees of experiences of social inequalities and grievances. As earlier disaster research clearly illustrates, such experiences are not direct results of "disastrous" or "sudden" events, such as the Indian Ocean earthquakes and the tsunami in December 2004. Rather, risks and vulnerabilities are results of longer-term processes of "failed or skewed development" (Wisner et al., 2012: 11), combinations of neglected disasters (Wisner and Gaillard, 2007), and increasingly part of the normal existence of people (Wisner et al., 2003: 4). Accordingly, analysis of disasters should not be segregated from everyday living (ibid.).

This article offers insights into everyday experiences in the aftermath of the 2004 Indian Ocean earthquake and the tsunami in Aceh, Indonesia, aiming to contribute towards scholarship that tackles the disaster management ideology of "build back better" that has since the tsunami in 2004 emerged as a global conceptual understanding of continuum of relief, recovery and postdisaster development (Fan, 2013; Feener, 2012; Daly et al., forthcoming; Jauhola, 2013).

I ask the following questions: What can we learn from the complexity of lived, "post-tsunami" experience in the city of Banda Aceh? In what ways do personal narratives, recounted "after the tsunami", challenge linear notions of transformation for "better", expectations of recovery, resilience and return to normalcy? What forms of social inequalities and silenced histories do those narratives illuminate?

Analysis draws attention to issues rising in a gendered and embodied posttsunami city: Struggles and contestations that become visible when shifting the 
focus from the big narratives of the tsunami and its aftermath to personal life stories. The article suggests a move away from simplistic categories of "tsunami survivors" or a "city that is built back better". Stories narrated in the following pages illustrate how the aftermath of the tsunami is experienced and lived in a wider and partly unsolved context of armed conflict, inequality, poverty and violence, and their gendered and sexualised impacts. Although, at the outset the tsunami, experience may have been central to creating common "aftermath" memory archives in Banda Aceh, I argue on the basis of my research data, that attention to the multiple experiential landscapes and their detail illustrates how the present and its connections to varying "disasters" is complex and diverse.

The article continues with an overview of the context of the tsunami and armed conflict in Aceh, existing literature on post-disaster Aceh, and key methodological considerations how the experienced post-disaster city is studied ethnographically. It then moves on to narrate seven ethnographic encounters in the provincial capital of Banda Aceh.

\section{Banda Aceh, the City That Rebuilt Itself after Devastation}

The provincial capital of Banda Aceh, located on the western-most tip of the island of Sumatra, was marked on global disaster maps in the aftermath of the Indian Ocean earthquakes and tsunami on 26 December 2004. With its epicentre just $100 \mathrm{~km}$ off the coastline of Aceh, it is estimated that the tsunami destroyed $61-85 \%$ of the city: over 78,00o of its pre-tsunami 269 ,ooo residents died, and its population was then augmented by more than 40,00o Internally Displaced Persons (ID Ps) in the aftermath (Mahdi, 2014: 268, 281).

It was estimated in the aftermath of the tsunami that around 88,0oo housing units needed replacement, while 71,00o partially damaged houses required substantial attention. Four years later more than 140,00o houses had been completed by over 120 aid agencies. Based on central government regulations of January 2005, all housing construction intended for earthquake and tsunamiaffected families/households had to follow the "six-by-six" model (i.e., $36 \mathrm{~m}^{2}$ ) although this was implemented in various ways by different organisations (Steinberg, 2007: 151, 155; Ahmed and O'Brien, 2011: 75). Thus, housing construction in Banda Aceh was far from identical across neighbourhoods or even within the same locale. Reconstructed neighbourhoods, or clusters of houses within them, became known not only by their official administrative village names, but also by donor: Turkish houses, Oxfam houses, UN-Habitat houses, Korean houses, CPR houses and BRR houses, just to name a few. Such names 
draw attention to the relationship between beneficiaries and the aid organisations but they also carry other symbolic and material value: residential desirability, and potential resale/renting value.

Banda Aceh, however, is also known as the capital of a province that is rebuilding itself after three decades of armed conflict between the Indonesian army and the Free Aceh Movement (GAM). The Helsinki Peace Process, initiated just days before the tsunami, led to the signing of a Memorandum of Understanding (MoU) between the two parties in August 2005, guaranteeing Aceh a position of self-government within the wider framework of the Republic of Indonesia. As part of the MoU, GAM agreed to demobilise its military troops and decommission all arms, ammunition and explosives, while the Indonesian army pledged to withdraw all non-organic military and police forces from Aceh, and stabilise the number and tasks of organic military and police forces in the province (for details, see, for example, May, 2008).

Banda Aceh was never a strong base for GAM during the conflict, but rather was seen as an administrative centre, with its political and bureaucratic elite siding with the central government. However, many of the central parts of the city centre were labelled as "black zones", no-go areas at night-time, due to gunshots and the threat of violence. Banda Aceh also became a destination for IDPs (internally displaced persons) fleeing the province's high-conflict regions (Mahdi, 2014: 276). Furthermore, despite the peace process, nine years after the signing of the peace agreement both the military and police forces continue to have a strong presence in the city: the riverbanks of the centre accommodate the army's provincial and district commands, district police command, and civil service and Sharia police. Meanwhile, many ex-combatants have migrated to Banda Aceh in search of employment and business opportunities, but also as politicians (Aspinall, 2009a). It is common to see police, military and excombatants patrolling the public parks and parking lots.

The physical reconstruction of the city has made the visible scars of the tsunami disappear, though there are numerous memorials constructed by tsunami aid to commemorate the loss and destruction. Nowadays visitors can join formal tours that visit the different "tsunami sites" in the city: the tsunami museum, a boat on the roof of a house, mass burial grounds, the tsunami education park, the "Thanks to the World" monument and so on. By 2011, the population of Banda Aceh had returned to its pre-tsunami figure with the biggest demographic increase indicating a simultaneous "baby boom" and inmigration of young adults (Mahdi, 2014: 282-283). 


\section{Scholarly Focus on "Post-Disaster" Aceh}

Over the years, rich academic research on the post-tsunami Aceh has emerged both locally and outside the region: ethnographic and anthropological accounts of the aid effort and the politics of humanitarian aid (Jauhola, 2013; Grossmann, 2012; Grayman, 2012); studies focusing on the role of religion and Islamic politics in the aftermath (Feener, 2012; Salim and Sila, 2010; Kloos, 2013; Ichwan, 2007); and analysis of the armed conflict and peace process in Aceh, focusing in particular on the latter's political economy and the transformation of combatants into the politicians, governors and businessmen of the province (Aspinall, 2009a,b; Törnquist et al., 2009; Miller, 2009; Sindre, 2014; Stange and Patock, 2010). Several of these scholars have also addressed the policy rhetoric of "building Aceh back better" adopted by humanitarian organisations and the Indonesian government as part of post-tsunami reconstruction efforts (see also Daly et al., forthcoming). With the financial and strategic policy emphasis on the tsunami reconstruction, however, conflict reconstruction has been marginalised and politicised in overall disaster response (Waizenegger and Hyndman, 2011).

Recent anthropological accounts of post-tsunami survival have drawn attention to emerging subjectivities, experiencing subjects and "the everyday" in order to give voice to people's stories of their lived experience in reconstructed neighbourhoods of Banda Aceh (Samuels, 2012; Kloos, 2013). As housing replacement was one of the core sectors of post-tsunami reconstruction, several scholars have examined it from the perspective of aid accountability and participation (Daly and Brassard, 2011), but new work is also emerging on the alterations and modifications made to the post-tsunami aid houses (Ahmed and O'Brien, 2011; Elliott, 2014). This research has made it clear that the impacts of natural hazards are complex products of social, political and economic environments, which are irreducible to simplistic, linear and "one description fits all" narratives.

\section{Ethnography in a Post-Disaster City}

This article draws on my ethnographic and personal narrative research in the commercial and administrative city centre in Banda Aceh (2012-2015), focusing on how my research interlocutors narrate their lives and make sense of their experiences, eight to ten years after the tsunami. In this article, my focus is on their embodied experiences of "home" and "belonging". Anthropological accounts of "home", and feelings connected to home, domestic space and 
uprootedness, suggest that understandings of the concept are multidimensional and negotiated: they are not reducible to a physical construction or a house, but related to place, space, feelings, practices or an active state of being in the world (Cieraad, 2006; Jackson, 1995; Mallett, 2004: 65; Ward, 2003: 81; see also analysis of housing construction after Hurricane Katrina in Levine, 2008).

Whereas the majority of previous studies on Aceh have either focused on emerging subjectivities vis-à-vis their tsunami experience, when approaching the lived and experienced city in my ethnographic research, I practiced openness that I have called ethnography of "here and now" (Jauhola, 2015) to the possibility that other historical and personal experiences, or material and spatial references, emerge as significant topics or themes of discussion during the ethnographic encounter. To protect the safety of the individuals concerned, I use pseudonyms and precise places of residence are not revealed.

The research discussed here aligns with such ethnographical approaches that have abandoned the formerly dominant mode of "realism": that is that a coherent account of whole societies is achievable. Instead, the focus is on the fragments and multiple voices of the city (Waterson, 2007:27). Focusing on the micro-level and its detail enables the construction of a better understanding of the histories, socio-cultural orders and social dimensions of post-disaster presence. Thus, I approach the post-disaster city of Banda Aceh from the perspective of the experienced and lived everyday, understanding this, and the social practices it produces, as an active site of struggle over legitimate subjectivities. In this view, the city is reincarnating through the social practices of its multitudes, and is therefore in a state of fluid transformation, rather than unchanging stability.

\section{Story 1. Layered Exile and Displacement}

On a busy commercial road in Banda Aceh that bustles with car and motorbike traffic, there is a simple, wooden-structured coffee shop-cum-dwelling, squeezed between restaurants, bakeries, banks and branded shops selling items from shoes and fashion to motorbikes and sports equipment. The makeshift coffee shop-cum dwelling consists of a simple terrace with tables and chairs for customers, kitchen-cum-coffee preparation sink, and tiny spaces separated by plastic sheeting for personal hygiene, prayer and sleep. The tin roof is leaky and covered with old cardboard boxes to protect residents and customers from the rain. Plastic sheets and heavy wooden planks are used to demarcate the coffee shop's opening hours according to the daily prayer sched- 
ules, although the boundary between private and public, open and closed, is flexible, and friends, family members and regular customers drop in even if the coffee shop seems closed.

There were always many such coffee shops in Banda Aceh in the past. These light, low-cost, wooden constructions have been important gathering points, especially for adult men, in most neighbourhoods and villages, and form important spatial anchors for constructing Acehnese masculinity (Jauhola, 2013: 121; Aspinall, 2009b: 93). Yet, the ongoing urbanising transition of the city after the tsunami coupled with a growth in middle-class consumerism, has meant that up-market coffee shops with espresso and milk foam machines and baristas are becoming increasingly popular amongst the wealthier class.

This coffee shop is run by a married couple in their fifties who have occupied the plot of land since they took refuge from the armed conflict in North Aceh roughly 15 years ago. The city is changing around them rapidly. Intensified land use for commercial purposes, and face-lifts orchestrated by the municipal government, have meant that people in similar circumstances nearby have either removed their belongings and self-built structures, or had them destroyed by the civil service police or public order officers. In fact, this couple consider themselves lucky that the current owner of the land has not, so far, evicted them or demolished their premises. The uncertainty of their future, however, is repeatedly iterated in our discussions: "If we are evicted, where would we go? There is no return to North Aceh for us," I am told.

As they rent a commercial plot of land, no formal tsunami housing aid has reached the couple, although the provision for free housing was extended to cover those depending on rentals. When the tsunami waters washed away their previous coffee shop-cum-home, they took refuge further from the coastline, as did all other survivors: first in tents, and later in barracks, meanwhile returning to repair their shop as soon as possible to ensure that it would appear to be still permanently occupied and used. Their oldest son remains without regular cash labour and lives outside the city, though he and his children are regular visitors bringing vegetables, eggs and snacks to sell in the coffee shop. The couple's only daughter is married with three children born after the tsunami, and lives in a similar makeshift house just behind her parents that is built from wooden planks, plastic and tin roof sheets, and squeezed between two older residential houses. She runs a small kiosk with her husband next to the coffee shop and her children spend most of their time after school in the street or visiting their grandparents.

Over the three years of contact, the fluctuation in the family finances has become evident; they also have to contend with the constant flooding, strong winds and rain that torment the terrace, the powerful smell of sewage, and the 
worn and broken furniture. The coffee shop has fewer and fewer customers and, in a concrete attempt to increase the cash available for the extended family, the wife starts to recycle plastic and cardboard boxes. I am told of this with some embarrassment, as there is considerable stigma attached to garbage collection and recycling. Yet, these earnings are vital to ensure their grandchildren's education and to cover their own medical costs as they both have chronic health issues with their eyes, and constantly aching bodies.

The husband exhibits his combatant past on the coffee shop walls, thereby producing a non-verbal, yet emphatic, exhibition and remembrance of the armed conflict and the markers of his identity: a coffee shop advertisement that replicates the colours of the GAM/Partai Aceh ${ }^{1}$ flag; an enlarged ID-card photograph of him in a combatant gear placed high up on the kitchen cupboard; and old calendars with photographs of the MoU signing ceremony in Helsinki in 2005. The coffee shop also provides a space for ex-combatants to discuss ongoing political and economic transformation and business opportunities. Yet, when alone, the owner gives his own, slightly differing, account of the peace process in Aceh. He does not belong to the inner circles of the ex-combatants who have financially secured their lives through contracts or new businesses (Aspinall, 2009a) and he asks: "Where is that reconstruction aid meant for the ex-combatants?" Imprisoned twice and taking refuge with his family in Banda Aceh after his second escape, he never talks directly of his role in the armed conflict other than to say that he belonged to the original generation of independence fighters that founded GAM in 1976 and that he was imprisoned, mutilated and interrogated several times by the Indonesian army. He is a man of quiet thought though he shows loving affection to his five grandchildren when they visit the coffee shop.

It is through his wife that I hear of the past events that have brought insecurity and violence, systematic rape and demolition of houses in North Aceh. "These are not my experiences," she sometimes clarifies, "but things that I've heard from others." Whether that is a strategy of distancing herself in order to secure emotional and physical wellbeing, or a story that is told to a foreign researcher who is interested in personal narratives in Aceh, it is difficult to say. Yet, for a researcher, such stories, regardless of their authenticity or degree of verification, carry invested emotional significance (Waterson, 2007:15) that tells of the multiple, at times silenced, landscapes of conflict experience. The

1 Partai Aceh, controlled by the leaders of the GAM, was established in 2008 and has contested since the 2009 legislative elections when they gained $47.8 \%$ of the provincial legislature votes; by April 2014, however, their support had decreased to just below $36 \%$. 
provisions for a human rights court and truth and reconciliation processes articulated in the MoU in 2005 are yet to materialise in Aceh.

During the months preceding the parliamentary elections in April 2014, pessimism about the benefits of the peace process increase. The local newspapers document violent incidents and internal divides between ex-combatants. Reflecting upon the news and his doubts of the sustainability of the peace process the husband comments: "Kabar Aceh tubuh baik, tapi kabar pemikiran Aceh masih kurang baik," translated roughly to: "If you ask 'how Aceh is doing', physically Aceh/Acehnese are doing well, but thoughts/thinking, less so."

One day, in passing, I am told that the land they occupy had belonged to someone who went missing during the massacre of 1965-1966 that targeted the political Left, communists and ethnic-Chinese communities (Kammen and McGregor, 2012; Melvin, 2014). Following the massacre, land was commonly seized from people accused of being PKI members and handed over to a plantation company that was state-owned and connected to the military. The only reminder of the past is the written ban next to the coffee shop: "Forbidden to construct a kiosk on this land. Province of the Special Territory of Aceh." It silently tells the story of the slaughter of half a million people across the Indonesian archipelago, escalating from the initial killings in Aceh in October 1965 and leading to the flight of thousands of people to Medan, a violenceled migration pattern (Tsai and Kammen, 2012; Melvin, 2013) that features in another story in this article.

After the elections, the ex-combatant husband redecorates the cupboard wall with new enlarged laminated photographs with pictures of himself and a number of his deceased heroes: the founder of GAM Dr. Hasan di Tiro; charismatic Naqshbandi sufi ulama Abu Ibrahim Woyla from West Aceh; GAMaligned ulama Teungku Muhibuddin Waly; and Abu H. Abdussamad bin Usman. The text in one photo reads:

O Allah show us, Acehnese people, the right path and give us the opportunity to care for the welfare of our grandchildren with the wealth that had been left by our ancestors.

May Allah bring peace and blessing into your life and home!

\section{Story 2. Unusual Woman, Unfit for the Neighbourhood?}

One day, a woman in rubber boots and dirty work uniform drops by for a coffee break. This is unusual as the only other Acehnese female customer has been a 
teenage girl waiting for her boyfriend to finish his work shift in a nearby shop and who was later reprimanded by the owner: he does not allow people to commit khalwat ${ }^{2}$ sins in his coffee shop. As we engage in conversation, I realise that she is one of my very first research interlocutors but with whom I later lost contact. The municipality gardening and cleaning department had transferred her from the municipality nursery to work on the trees and flowers planted on the roadsides and intersections and, although she was in charge of the area that was central to my street ethnography, our paths had not crossed again.

She is in a hurry to return to work but invites me to visit her and her familyshe is the single head of household with three teenage children - when her afternoon shift is over. Later, making our way to her home, she reveals to me how difficult she finds it to live in a religiously conservative neighbourhood: she is considered to be dissident, improper and immoral and her children have shoes thrown at them on their way to and from school. Their neighbour has made sure in every possible way that her family members know they are not welcome in the neighbourhood. Why? Because she has not remarried after the death of her husband, she is not accompanied by a muhrim ${ }^{3}$ when moving around the city, and she works outside the house in a male-dominated job. Yet, she has no-one to turn to. There are no relatives left after the tsunami.

The neighbourhood discrimination has impacted in a number of ways on her everyday life: physically, mentally, socially and economically. Her house, reconstructed after the tsunami, is located alongside the village road yet due to its proximity to the vocally discriminative neighbour opposite, the family never uses the main front door. Instead, what is usually considered a so-called "back stage" (i.e., back door leading to toilet/bathroom) had become the new entrance to the house, while the front door and the two windows facing the road and the neighbour were blocked with blankets and plywood sheets making the two rooms facing the road dark; their only access to daylight was the back door that was kept open for that purpose and for ventilation. I was told that this was a strategy to gain distance from the neighbours and block the view into the house from the street.

2 Khalwat, close proximity between sexes who have no kin or spousal relationship in isolated places was stipulated as an offence in the provincial by-law Qanun 14/2003 and further amended into ikhtilah, intimacy between unmarried couples in either open or public space, in various versions of the Islamic Criminal Law Qanun Jinayat between 2008-2014. The latest version of the law was passed by the provincial legislature in September 2014 but it is yet to be enforced and several civil society actors aim to challenge its validity under the constitution of Indonesia due to several other problematic provisions.

3 Muhrim (Indonesian, mahram in Arabic) refers to unmarriable kin. 
The dark rooms and blocked windows and front door provide a material anchor to her feelings of exclusion and discrimination. However, next to her "new front door" there is a small plot of land where she grows plants and dries fruits in the sun, while the rice field beyond provides landscape views. This is her world and the space that she knows well. Having given up selling fish at the local bus terminal due to lowering income, she had retrained herself to become a gardener. Her knowledge of plants and their healing properties and value is her hidden expertise: She can state exactly the worth of certain seeds and how much they are valued in the Middle East and beyond.

As she struggles to pay the tuition fees of her teenage children, the house remains barely furnished, with concrete floors that are severely damaged after some seven years of usage. Being categorised as dissident in the village has also meant that the village head has refused to add her name to the list of people eligible for social benefits from the provincial government. Instead, the Islamist party PKS that approached potential voters around upcoming elections included her family as beneficiaries of their monthly social benefits. To secure sufficient monthly earnings, she and her children also produce and package dried potatoes and sweet potatoes in small portions that are then sold in street corner kiosks or by people who trade in public parks and popular gathering points, such as the tsunami museum.

Her story raises a number of questions: was gardening purely a means of livelihood? Or did it provide other means of creating space and agency for herself? It required hard physical labour, yet it seemed that her stories about her work and knowledge of plants were told jokingly and with humour, and provided with her a sense of belonging woven like a rhizome through the city.

\section{Story 3. Tsunami Solidarity and Batak Food in a Bad Neighbourhood}

I visit this neighbourhood for the first time at the invitation of a family who earn their livelihoods in several public parks by providing entertainment to children and their parents: henna tattoos and amusement park equipment. Located in close proximity to the main market, mosque and the Aceh river, this neighbourhood is regarded as an area of immorality, gambling, prostitution, murders, crime and violence by the residents of Banda Aceh-a home to those labelled as "outsiders" and "non-Acehnese": migrants, wage labourers and temporary dwellers who have moved into the city in the aftermath of the tsunami with aspirations for a better life. 
This couple are migrants to Banda Aceh, the wife from North Sumatra and her husband from South Aceh, yet their story does not fit the assumed "post-tsunami" migration narrative. Rather, it begins roughly 15-20 years earlier and relates to conflict migration, economics and kinship ties that are formed between ethnicities, provinces and religions. During one of my visits to their house-it is noon, before the tasks at the park begin and whilst waiting for the husband to pick up the children from the school - the wife tells me her tsunami story. She was alone at home, on a day just like this one, heavily pregnant with their first baby. Scared by the tremors of the earthquake, she left the house for the main village road where a number of Chinese-owned, three-storied commercial buildings are located. The support she was offered there is emphasised in her account. She was given shelter and together they all climbed to the highest floor to be safe from the tsunami water that rushed through the neighbourhood, destroying most of the buildings and flooding all that remained. Retelling the events of that day seems painful, yet she pushes herself to finish her narration: how she was worried she would not find her husband again; her concern that he might think she had died; her fears for her unborn baby and for their relatives and neighbours. Given her condition, she was offered an airlift to Medan by one of the aid agencies to give birth to her child, returning to Banda Aceh when it was safer.

It seems that ten years after the tsunami their lives are normalised: they have two more children all born after the tsunami, a house that they have extended by building a new kitchen themselves, and reasonably stable livelihoodsmade through entertaining the expanding middle classes of Banda Aceh which provide economic security, a consumerist lifestyle and the possibility of good schooling for their children. However, moments of silence, listening to the sounds of the palm trees and rice fields, are filled with sorrow and pain that is hardly verbalised, but rather expressed through looks, gestures and gasps. Constructing the house anew had been far from a simple matter. Residents had taken part in processes wherein the beneficiaries, the order of construction, and the choice of building materials were discussed and debated. Some of those attending were beaten up by other angry residents and could no longer return to the neighbourhood, while the husband, having been a go-between for the conflicting parties, was threatened but never physically attacked.

During the busiest periods of park events and normal weekends, their "sixby-six" tsunami home is merely a place for rest, and for accommodating family members visiting them from other parts of Aceh and North Sumatra. The family, including the three children, spends most of the day from early afternoons until midnight at their regular park where, since its reopening in 2007, hundreds of emerging middle-class families bring their children to play. It is 
a place to see and to be seen. However, over the years, attendance at public parks has decreased: frequent rains, whether a quick shower in the afternoon or heavy, hour-long monsoon downpours, coupled with the newly-constructed air-conditioned shopping malls, mean that business on some evenings is quiet. Moreover, park vendors complain that the ex-combatants employed as park security guards have introduced their own informal "security payments" on top of the formally paid fee to the municipal government. Whilst the parents are busy with park visitor customers, the children play in the park; the family dinner is bought from the street vendors and shared at a park table where other friends, relatives and park entrepreneurs gather to chat and gossip.

"I am no good at cooking." She looks at me and laughs, "But come and join me for lunch at our house." The neighbourhood comprises a mixture of ethnicities allowing her the luxury of buying her Batak staple food from the street: A marker of belonging and connectedness in a bad neighbourhood.

\section{Story 4. Moving between Homes and Gendered Expectations}

The narrator of this story provides entertainment for small children by putting in hours of physical labour, bicycle-powering a merry-go-around. While it now requires heavy maintenance, frequent repair, and at times causes several hours of lost income, the machine had once supplied by post-tsunami reconstruction aid promoting new livelihoods, and belongs to a woman in her thirties. She is divorced and recently remarried to an ex-combatant who, at the time of our first encounter in 2012, was serving a one-year sentence in prison for possession of marihuana. Home for her, then, consisted of a number of houses located in completely different parts of the city that I was invited to visit: we lunched with her ex-husband, who had vacated the now empty and unused tsunamiaid house after their divorce and lived in a smaller wooden hut just behind it; we visited the prison where her tasks included bringing her new husband medicine for his conflict-injured and infected leg, collecting his dirty clothes for washing back at her house, and carrying letters to the ex-GAM governor pleading for medication for his leg injury that neither the prison, nor he or his family could afford.

During my encounters with the residents of Banda Aceh, I realised that alongside the more formal state and municipal governance-led social welfare schemes, these letters, and favourable response to them by those in power, were an important way of attaining social security in the aftermath of the tsunami and the conflict. Yet, these letters also told a story of reliance on patrimonial patron-client relationships and underlined the hierarchical nature 
of the political economy after the tsunami-letters that were performative in terms of power and its hierarchies, and a collective tie to the leader (Nordholt and van Klinken, 2007:4).

During her husband's sentence it seemed that, although the constant visits to the prison caused her stress, she was feeling quite content, perhaps because she was in charge of her own life, and surviving economically on just her own earnings. This seemed sufficient on a good day and when healthy and able to pedal. The park also seemed to offer a female space consisting of networks of women ready to reflect upon the gendered expectations of their lives, joke about men, and create spaces of leisure in the midst of hard physical labour.

As the release of her husband approached, her worries grew. How would they reintegrate their lives together? How would she and her children's lives change, as stories about new husbands and their ways of treating stepchildren told at the park were not encouraging? An especially traumatic experience, repeatedly narrated by these women, was the case of a rape and murder of a sixyear old girl, Mardiana, also known in public as "Diana", by two men who had brought her to play in the same public park, one of whom was her under-aged uncle. Weeks before her husband's release, coinciding with the forthcoming parliamentary elections, ex-combatant friends of the husband, with massive stone rings, expensive watches and mobile phones, accompanied by young women, whom they introduced as "nieces", started visiting the park frequently and inquiring information about him. He and his comrades had moved to Banda Aceh from East Aceh after the MoU was signed.

The arrival of the husband changed the household dynamics, but also the dynamics at the park. The children began complaining; the husband grumbled about the children taking his motorbike; and the wife looked increasingly tired when arriving at the park with the merry-go-around, complaining: "My life was so much better without him." His being unable to fulfil expectations of a man being the head of the household and in charge of family finances was difficult for both of them. Despite his injured leg, he visted the park in the evenings carrying brochures about water purifiers and dispensers, and herbal products meant for home sales, meanwhile boasting about his big business plans based on promises made by other ex-combatants to involve him in bigger projects back in his own district. All of these would materialise once he was reunited with his commander though that moment seemed to remain permanently in the future- as did the promise for a cure for his injured leg, which the rumour had it, had been made by the current governor himself. In November 2014, the leg was finally operated on in East Aceh, but the infection has swollen the leg badly. 


\section{Story 5. Street Punks Occupying the Streets as Their Home}

"Why are you friends with them? They are filthy!" complain vendor women when they see me talking to the group of young street punks who gather at the park to wait for the maghrib prayer to end. These teenager/young adult punks play ukulele-sized guitars, makeshift drums made from plastic tube and rubber, and sing famous Indonesian anarchist and punk songs at the commercial city centre.

Mama, I'm coming home, please heal my injuries. I miss the table, to have tea with you

Song 'Film murahan'; lyrics by Rом \& The Jahats

At times followed by girls, wannabe ladies punk, or just other street children, this is the Tsunami Museum street punk community that became known internationally after their arrest and re-education in December 2011 (Idria, 2013; Jauhola, 2015; Jauhola and Bolong, 2014). Using their punk bodies—black clothes covered with DIY patches, tattooed faces, arms and legs, pierced noses, lips and ears, coloured and shaved hair-they embody the uncertainty and (self-)inflicted gendered pain of the city. Labelled as filthy, improper, antiIslamic, Western products, they occupy the public space despite lengthy efforts by the municipal government assisted by police force and vigilante groups to put an end to punks in Aceh.

Using public space - such as the Tsunami Museum - to gain punk visibility, the city itself becomes their stage and home: Symbolically, but also concretely, as many of their belongings, such as toothbrushes, clothes, shoes, and DIY equipment for tattoo making and screen printing are kept in various locations around the city. Spending nights in wrecked and empty houses, parks and back allies, they form new kinds of intimate and caring relationships through bodily practices, and establish friendships across the Indonesian archipelago and the rest of the globe via social media and visitors from outside, such as researchers, documentarians, journalists, and punk rocker and anarchist tourists who might retell these stories beyond Aceh. Yet, what seemed at first to be a coherent single local community, was in fact one in constant change and movement: sub-groups emerged, individuals were evicted, some left and joined other punk groups or found work elsewhere in Aceh, North Sumatra or Malaysia.

The security apparatus challenges this group and their right to use public parks to sleep in at night: Practices such as bedding down on children's playground equipment, for instance, were formally banned by the municipal government, leading to forced evictions. Over time, however, access to the 
spaces has been negotiated with individual security guards who, after being introduced to, and becoming familiar with the members of the community, accommodate their needs for sleep and rest, though this is based on individual patron-client relationships and trust. Any changes to security personnel means re-negotiating the spaces each night, and at times several times per night.

What about their relationships to their parents and homes? Those vary. Although dominated by young-adult punks, some who have lost their parents and siblings in the tsunami, the community also consisted of under-aged youth on the run, whose families were trying to locate them as they were worried if they had not been home for a long time. Worried adults also included at least one state-legal aid officer seeking her client in an effort to enforce institutionalisation of a convicted under-aged adolescent. One member, an emerging leader within the community, deployed a punk identity to combat his late violent father and run away from a militarised home, ending up embodying the violence of the city himself after being beaten up by the military, police and prison guards during detention. There was another who, after several violent arrests and detention, severe drug abuse and loss of parents, joined an Islamist group and their ashram, thereby gaining a new family, later returning to the streets and his former punk community for $d a^{\prime} w a$, Islamic preaching. In October 2014, the community mourned the death of one of their younger brothers, Romi Borjong (Medan slang which translates as "Romi the ghost"), who died after being run over by a car in Palembang in South Sumatra.

\section{Story 6. Moving Houses, Coming to Terms with the Past}

In this story, home is constructed in multiple locations in Banda Aceh and Medan; it is shifting due to multiple dramatic events in the past. The story belongs to an ethnic Chinese woman in her thirties, who was born in Medan and abandoned at the Buddhist temple to be later adopted by a Banda Acehnese woman. Having lived most of her life in the Chinatown of Banda Aceh she now lives in Medan. We had met six months earlier in Banda Aceh, only a few months after an Islamist group had attacked the Sunday mass of a Christian Pentecostal congregation of which she was a member. Despite several applications, the congregation had not been granted a formal licence for worship by the municipal government, and thus Sunday mass and children's Bible school was arranged in a converted commercial space behind metal security doors. She had no hatred towards the attackers, I was told. Yet, from the intensity of her description of the events it became clear that they had left marks on her understanding of basic safety in a neighbourhood where she had lived all her life. 
Now six months later, having followed her husband to Medan, leaving two of her sons in the care of her adopted mother in Banda Aceh, growing distrust of her mother is turning into agonised feelings of loss. "I never was close to her" she says, "I was brought up by my grandmother who died in the tsunami." Suspecting that she has disappointed her mother, who wished her adopted daughter to become as successful as she had once been in the beauty salon business, she feels that her mother appreciates very little, if anything, about her. On the contrary, the memory of her deceased grandmother- "taken away by the tsunami" - seems to play a crucial role in any feelings she has of emotional belongingness and worth: "She was the only one that paid attention to my details, my marriage, my needs, my feelings." Telling me about a violent exhusband, she says that only her grandmother had cared enough to say to her directly, "Don't lie to me, I saw your bruises, don't lie to me. I never planned to give you to a man who would do something like this." She continues, "My grandmother's neighbourhood was washed away in the tsunami. When I lived in Banda Aceh I regularly went to the ruins of her house to cry and commemorate her ... But now I try to move on, accept my past, move on day by day and I just let it flow, let it flow."

\section{Story 7. Queer Homelessness-Seeking Safe Space in the City}

In March 2014, Serambi Indonesia, local newspaper in Aceh, published an article on its cover page entitled "Residents raid a lesbian couple" (Serambi Indonesia, 2014b). "Neighbourhood Watch", initially warned of a possible khalwat case, stormed into a house, found two males and two tomboyish females, brought them to the village head, contacted the Shari'a police, and informed the local media. In the article, the village head says that the arrested individuals come from "broken homes" and that gays and lesbians are known to gather at that particular house. In October, the same newspaper cautioned Acehnese, especially all parents and teachers, to prevent "outbreaks" of a LBGTI pandemic and to be vigilant not only about khalwat opposite sex offenders, but also about those of the same sex (Serambi Indonesia, 2014a).

Having followed the Banda Acehnese queer scene ${ }^{4}$ since 2006, I knew this was nothing new (Jauhola, 2013: 70-79), nor should it to be labelled as an

4 By queer I refer to such non-normative forms of gender and sexuality that are not reducible to sex binary and heteronormative sexual practice, but also not necessarily reducible to transnational LBGTI, Lesbian, Bisexual, Gay, Transsexual, Intersex activism. 
Acehnese "exceptionality" given the overall increase of homophobic violence in Indonesia since the fall of the authoritarian regime in 1998 (Boellstorff, 2004). Yet, in the Acehnese context of recent formal implementation of Shari'a lawrejuvenated in the aftermath of the tsunami and with reconstruction funding (Feener, 2013) — consensual same-sex acts are not only considered morally improper, but, since the first elections after the peace agreement, the provincial government has initiated and passed a local regulation that criminalises liwath and musahaqah ${ }^{5}$ through the newly-formed State Shari'a Agency (Dinas Syariah Islam) as part of the overall attempt to enforce Islamic Criminal Law in Aceh. The latest attempt was in September 2014 when the provincial legislators approved the bill in their last session of their electoral term. It is yet to be seen if this piece of legislation is finally enforced, as it seems that the Ministry of Home Affairs is prepared to review the law and civil society actors have requested for a judicial review based on other discriminative provisions in the law. Although the criminal law is yet to be enforced, local authorities have tested their ability to criminalize homosexual acts: on 29th September 2015 two lesbians were arrested and put to 'rehabilitation' on the grounds for hugging in public using the by-law 11/2002 on Aqidah (Theology), Ibadah (Rituals) and Syiar Islam (Islamic Festivals), causing others to hide and feel insecure of their futures in Aceh.

From the perspective of individual queers living in Banda Aceh, the above developments have shrunk the number of safe spaces available in the city, resulting in constant awareness of unwelcome visibility, and increased worry of the safety of living arrangements, even in privately-owned properties. Stories of forced evictions and the threat of physical violence have meant that living in rental properties has become temporary and precarious. The recent death of an HIV positive, transgendered person in one of the urban neighbourhoods, for instance, was narrated to me with distaste. Pointing in the direction of the deceased person's house and grave I was told: "No-one went to that funeral." This clearly suggested a total isolation from the tsunami-reconstructed neighbourhood. Yet, this image of isolation was only a partial truth, as the funeral and private commemorations were organised by people outside her neighbourhood: her salon worker colleagues, the queer community and organisations providing care for the HIV-positive in the city.

5 The by-law passed by the provincial legislature defines liwath as anal sex and musahaqah as sexual arousal between females that is caused by rubbing their vaginas or other body parts together. 


\section{Conclusions}

This article was motivated by a challenge posed by anthropologists studying the personal narratives and everyday lives of "small people" (orang kecil in Indonesia, the ones without power). Based on seven stories reflecting upon "home" and "belonging" chosen from the ethnographic and personal narrative research conducted in Banda Aceh between 2012 and 2015, several themes emerge as potentially new ways of looking at the reconstructed city: layered exiles and displacements; hidden and forgotten narratives of violence and grief; (un)met gendered expectations being a male and female; economic struggle and longing for better lives; the hierarchical political economy of post-conflict and tsunami reconstruction; multiple ways of arranging ones' lives; and volatilility and vulnerability combined with remembrance, cherishing loved ones and forming caring and loving relationships outside the normative notions of nuclear family and home.

These stories give insights to the diversity of the experiential post-disaster city of Banda Aceh. They point towards intersections of gender, social class, ethnicity, religion and urban experience, giving rise to the and observation that a positionality as "other" does not automatically translate into an intercommunal sense of solidarity: as the punks put it, "We are not them: we are not GAM, we are not lesbians."

The stories in this article illustrate that no story of the post-tsunami, postconflict reconstruction can be told fully, or simplified into catchy phrases such as "New Aceh" or "Aceh that is built back better" or easy technical reconstruction intervention logic. Rather, lived experiences in the aftermath of the tsunami challenge us to look at the mundane and everyday. Such focus challenges the terms we use and the ways in which we look at the city as it is today. The aftermath of the tsunami is a contested site that draws attention to dynamics of the armed conflict, poverty and multiple forms of violence-and their gendered and sexualised impacts. Focus on the contestation, fragments and the multiplicity of voices enables the construction of a better understanding of post-disaster lives - and socio-cultural order of disaster. The mundane, and the micro level experiences suggest that besides the natural hazards, there are parallel and multiple disasters and new vulnerabilities that one needs to remain sensitive towards, in order to gain a fuller picture of post-disaster reconstruction realities. 


\section{References}

Ahmed, Iftekhar and David O'Brien (2011) "Self-Initiatives and Transformations: PostTsunami Housing in Aceh, Indonesia”. International Journal of the Constructed Environment 1: $73^{-86 .}$

Aspinall, Edward (2009a) "Combatants to Contractors: The Political Economy of Peace in Aceh". Indonesia 87:1-34.

(2009b) Islam and Nation: Separatist Rebellion in Aceh, Indonesia. Stanford, CA: Stanford University Press.

Boellstorff, Tom (2004) "The Emergence of Political Homophobia in Indonesia: Masculinity and National Belonging". Ethnos: Journal of Anthropology 69: 465-486.

Carrigan, Anthony (2016) "Towards Postcolonial Disaster Studies", in Anna Bernard, Ziad Elmarsafy and Stuart Murray (eds) What Postcolonial Theory Doesn't Say. London: Routledge, pp. 202-221.

Cieraad, Irene (2006) At Home: An Anthropology of Domestic Space. New York: Syracuse University Press.

Daly, Patrick and Caroline Brassard (2011) "Aid Accountability and Participatory Approaches in Post-Disaster Housing Reconstruction". Asian Journal of Social Science 39: 508-533.

Daly, Patrick, Michael Feener, Marjaana Jauhola, and Creg Thorburn (forthcoming) "The Rhetoric of Change: Re-Imagining Life in Post-Tsunami Aceh, Indonesia", in Patrick Daly and Michael Feener (eds.) Rebuilding Asia: Approaches to Post-Disaster Reconstruction in the Asia/Pacific Region. Cambridge University Press.

Elliott, Catherine (2014) "At Home in the Post-Tsunami Landscape? A Case Study of Post-Disaster Housing in Aceh, Indonesia”. Ph.D. thesis, University of Tasmania.

Enarson, Elaine and Maureen H. Fordham (2001) "Lines That Divide, Ties That Bind: Race, Class, and Gender in Women's Flood Recovery in the Us and UK". Australian Journal of Emergency Management 15(4): 43-53.

Enarson, Elaine and Lourdes Meyreles (2004) "International Perspectives on Gender and Disaster: Differences and Possibilities". International Journal of Sociology and Social Policy 24(10/11): 49-93.

Fan, Lilianne (2013) “Disasters as Opportunity? Building Back Better in Aceh, Myanmar and Haiti”. HPG Working Paper. London: Overseas Development Institute.

Feener, R. Michael (2012) "Social Engineering through Shari'a: Islamic Law and State-

Directed Da'Wa in Contemporary Aceh". Islamic Law and Society 19: 275-311.

(2013) Sharia and Social Engineering: The Implementation of Islamic Law in Contemporary Aceh, Indonesia. Oxford: Oxford University Press.

Grayman, Jesse Hession (2012) "Humanitarian Encounters in Post-Conflict Aceh, Indonesia". Ph.D. thesis, Harvard University.

Grossmann, Kristina (2012) "Women as Change Agents in the Transformation Process 
in Aceh, Indonesia", in Andrea Fleschenberg and Claudia Derichs (eds.) Women and Politics in Asia: A Springboard for Democracy? Singapore: Institute of Southeast Asian Studies, Pp. 97-122.

Ichwan, Moch Nur (2007) "The Politics of Shari'atization: Central Governmental and Regional Disocurse of Shari'a Implementation in Aceh", in Michael Feener and Mark Cammack (eds.) Islamic Law in Contemporary Indonesia: Ideas and Institutions. Harvard Massachusetts: Harvard University Press, Pp. 193-215.

Idria, Reza (2013) "Cultural Resistance to Shariatism in Aceh", in Regime Change, Democracy and Islam: The Case of Indonesia. Leiden: University of Leiden, Pp. 180-201.

Jackson, Michael (1995) At Home in the World. Durham: Duke University Press.

Jauhola, Marjaana (2013) Post-Tsunami Reconstruction in Indonesia:negotiating normativity through gender mainstreaming initiatives in Aceh. London: Routledge.

(2015) "On 'Being Bored'-Street Ethnography on Emotions in Banda Aceh after the Tsunami and Conflict”, in Linda Åhäll and Thomas Gregory (eds.) Emotions, Politics, War. London: Routledge, Pp. 86-99.

Jauhola, Marjaana and Yudi Bolong (2014) "The street punks of the tsunami museum" (photoessay). Planet-The Welsh Internationalist 2014: 26-35.

Kammen, Douglas and Katharine McGregor (2012) The Contours of Mass Violence in Indonesia, 1965-68. Singapore: NUS Press.

Kloos, Davide (2013) "Becoming Better Muslims: Religious Authority and Ethical Improvement in Aceh, Indonesia”. Ph.D. thesis, University of Amsterdam.

Mahdi, Saiful (2014) "City Population Changes in Post-Disaster Region: A Case of PostTsunami Aceh, Indonesia”, in Mohamad Fahmi, Arief A. Yusuf, Muhamad Purnagunawan M. Budy P. Resosudarmo and D.S. Priyarsono (eds.) Government and Communities: Sharing Indonesia's Common Goals. Bandung: Un PAD-Press, Pp. 267290.

Mallett, Shelley (2004) "Understanding home: A critical review of the literature". The Sociological Review 52: 62-89.

May, Bernard (2008) "The Law on the Governing of Aceh: The way forward or a source of conflicts?" Accord 2008: 42-45.

Melvin, Jess (2013) "Why Not Genocide? Anti-Chinese Violence in Aceh, 1965-1966". Journal of Current Southeast Asian Studies 32: 63-91.

- (2014) "Mechanics of Mass Murder: How the Indonesian Military Initiated and Implemented the Indonesian Genocide, The Case of Aceh". Ph.D. thesis, University of Melbourne.

Miller, Michelle Ann (2009) Rebellion and Reform in Indonesia:Jakarta's Security and Autonomity Policies in Aceh. London: Routledge.

Schulte, Nordholt Hans and Gerry van Klinken (2007) "Introduction", in Nordholt H. Schulte and Gerry van Klinken (eds.) Renegotiating Boundaries: Local Politics in PostSuharto Indonesia. Leiden: KITLv Press, Pp. 1-29. 
Salim, Arskal and Sila Adlin (2010) Serambi Mekkah yang Berubah: Views from Within. Tangerang: Aech Research Training Institute.

Samuels, Annmarie (2012) "After the tsunami: The remaking of everyday life in Banda Aceh, Indonesia". Ph.D. thesis, University of Leiden.

Serambi Indonesia (2014a) "Masyarakat Aceh Perlu Antisipasi Lesbian dan Gay", Serambi Indonesia, 17 October. Available at: http://aceh.tribunnews.com/2014/10/17/ masyarakat-aceh-perlu-antisipasi-lesbian-dan-gay.

- (2014b) “Warga gerebek pasangan lesbian”, Serambi Indonesia, 13 March.

Sindre, Gyda Marås (2014) "Rebels and Aid in the Context of Peacebuilding and Humanitarian Disaster: A Comparison of the Free Aceh Movement (GAM) and the Tamil Tigers (LTTE)". Forum for Development Studies 41: 1-21.

Stange, Gunnar and Roman Patock (2010) "From Rebels to Rulers and Legislators: The Political Transformation of the Free Aceh Movement (GAM) in Indonesia". Journal of Current Southeast Asian Affairs 29: 95-120.

Steinberg, Florian (2007) "Housing reconstruction and rehabilitation in Aceh and Nias, Indonesia-Rebuilding lives". Habitat International 31: 150-166.

Tsai, Yen-Ling and Douglas Kammen (2012) "Anti-communist Violence and the Ethnic Chinese in Medan, North Sumatra", in Douglas Kammen and Katharine McGregor (eds.) The Contours of Mass Violence in Indonesia, 1965-68. Singapore: Nus Press, Pp. 131-155.

Törnquist, Olle, Stanley Adi Prasetyo and Teresa Birks (2009) Aceh: The Role of Democracy for Peace and Reconstruction. Yogyakarta: PCD Press Indonesia, ISAI.

Waizenegger, Arno and Jennifer Hyndman (2011) "Salient versus Silent Disasters in Post-conflict Aceh, Indonesia”, in Kirsch Scott and Colin Flint (eds.) Reconstructing Conflict: Integrating War and Post-War Geographies. Surrey: Ashgate, Pp. 67-9o.

Ward, Sally (2003) "On Shifting Ground: Changing Formulations of Place in Anthropology”. The Australian Journal of Anthropology 14: 80-96.

Waterson, Roxana (2007) "Introduction: Analysing Personal Narratives", in Roxana Waterson (ed.) Southeast Asian Lives: Personal Lives and Historical Experience. Singapore: Nus Press, Pp. 1-40.

Wisner, Ben and J.C. Gaillard (2009) “An Introduction to Neglected Disasters". Jámbá: Journal of Disaster Risk Studies 2(3): 151-158.

Wisner, Ben, J.C. Gaillard and Ilan Kelman (2012) "Introduction to Part I", in Ben Wisner, J.C. Gaillard and Ilan Kelman (eds.) The Routledge Handbook of Hazards and Disaster Risk Reduction. London: Routledge, Pp. 11-17.

Wisner, Ben, Piers Blaikie, Terry Cannon and Ian Davis (2003) At Risk: Natural Hazards, People's Vulnerability and Disasters. Vol. 2. Routledge. E-book.

Video on Book (VoB) version availabe at: http://scrapsofhope.info/scrapsofhome 